\title{
A Mn(II) complex of boradiazaindacene (BODIPY) loaded graphene oxide as both LED light and $\mathrm{H}_{2} \mathrm{O}_{2}$ enhanced anticancer agent
}

Xiao-Lei Xu, Jian Shao, Qiu-Yun Chen", Cheng-Hao Li, Meng-Yun Kong, Fang Fang, Ling Ji, Daniel Boison, Tao Huang, Jing Gao, Chang-Jian Feng
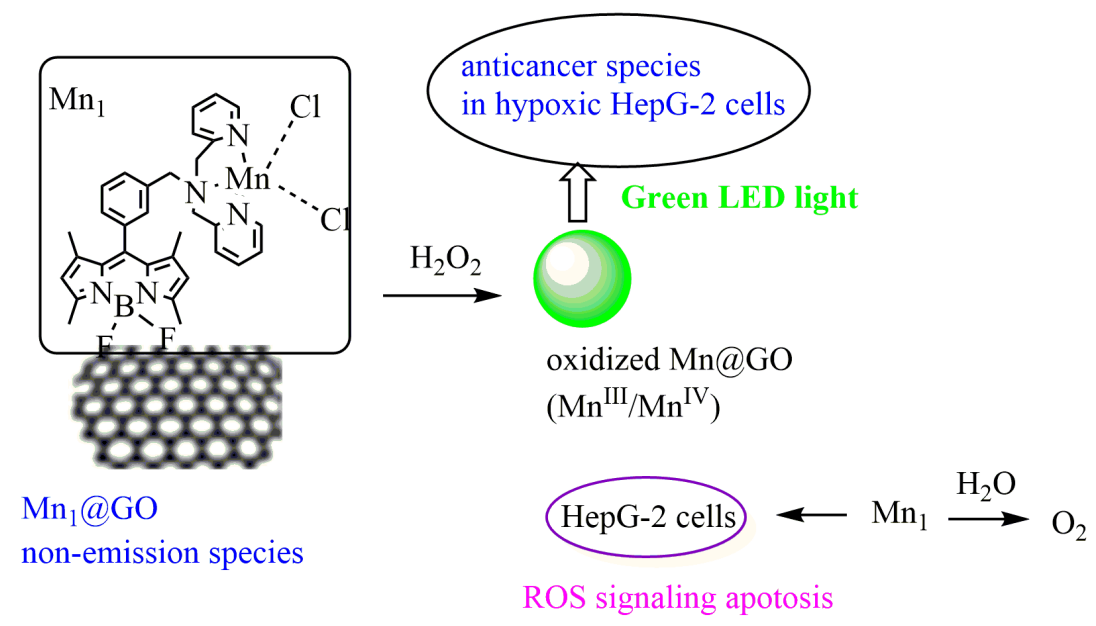


\section{A Mn(II) complex of boradiazaindacene (BODIPY) loaded graphene oxide as both LED light and $\mathrm{H}_{2} \mathrm{O}_{2}$ enhanced anticancer agent}

Xiao-Lei Xu ${ }^{\text {a }}$, Jian Shao ${ }^{\text {a }}$, Qiu-Yun Chen ${ }^{* a, b}$, Cheng-Hao Li ${ }^{\text {a }}$, Meng-Yun Kong ${ }^{\text {a }}$, Fang Fang ${ }^{\text {a }}$, Ling Ji ${ }^{a}$, Daniel Boison ${ }^{\mathrm{b}}$, Tao Huang ${ }^{\mathrm{b}}$, Jing Gao ${ }^{\mathrm{b}}$, Chang-Jian Feng ${ }^{\mathrm{c}}$

${ }^{a}$ School of Chemistry and Chemical engineering, Jiangsu University, Zhenjiang, 212013, P. R. China. Tel.: +8605118879800; Fax: +86051188791602;

${ }^{b}$ School of Pharmacy, Jiangsu University, Zhenjiang, 212013, P.R. China

${ }^{c}$ College of Pharmacy, University of New Mexico, Albuquerque, New Mexico 87131, USA

Corresponding author

*Tel.: +86 0511 8879800; Fax: +86 0511 88791602; School of Chemistry and Chemical engineering, Jiangsu University, Zhenjiang, 212013, P. R. China.

*E-mail address: chenqy@ujs.edu.cn (Q.Y. Chen) 


\section{ABSTRACT}

Cancer cells are more susceptible to $\mathrm{H}_{2} \mathrm{O}_{2}$ induced cell death than normal cells. $\mathrm{H}_{2} \mathrm{O}_{2}$ activatable and $\mathrm{O}_{2}$-evolving nanoparticles could be used as photodynamic therapy agents in hypoxic environments. In this report, a photo-active $\mathrm{Mn}(\mathrm{II})$ complex of boradiazaindacene derivatives $\left(\mathrm{Mn}_{1}\right)$ was used as a dioxygen generator under irradiation with LED light in water. Moreover, the in vitro biological evaluation for $\mathrm{Mn}_{1}$ and its loaded graphene oxide (herein called $\left.\mathrm{Mn}_{1} @ \mathrm{GO}\right)$ on HepG-2 cells in normal and hypoxic conditions has been performed. In particular, $\mathrm{Mn}_{1} @ \mathrm{GO}$ can react with $\mathrm{H}_{2} \mathrm{O}_{2}$ resulting active anticancer species, which show high inhibition on both HepG-2 cells and $\mathrm{CoCl}_{2}$-treated HepG-2 cells (hypoxic cancer cells). The mechanism of LED light enhanced anticancer activity for $\mathrm{Mn}_{1} @ \mathrm{GO}$ on HepG-2 cells was discussed. Our results show that $\mathrm{Mn}(\mathrm{II})$ complexes of boradiazaindacene (BODIPY) derivatives loaded GO can be both LED light and $\mathrm{H}_{2} \mathrm{O}_{2}$-activated anticancer agents in hypoxic environments.

Keywords. Manganese; Cancer; $\mathrm{H}_{2} \mathrm{O}_{2}$-activatable; Photodynamic; Graphene 


\section{Introduction}

Photodynamic therapy (PDT) is a clinical modality that employs a photosensitizer, an appropriate excitation light, and oxygen $\left(\mathrm{O}_{2}\right)$ molecules to generate cytotoxic singlet oxygen $\left({ }^{1} \mathrm{O}_{2}\right)$ for the treatment of cancers [1]. Although PDT has become a promising treatment option for early stage cancer and an adjuvant for surgery in late-stage cancer, tumor hypoxia severely reduce the therapeutic efficiency [2]. Hypoxia is increasingly being recognized as a characteristic feature of solid tumors. The photosensitizer-mediated consumption of $\mathrm{O}_{2}$ during PDT further potentiates tumor hypoxia. Thus, the application of traditional PDT agents is significantly limited by the tumor hypoxia due to the $\mathrm{O}_{2}$-dependent nature of PDT [3]. Thus, it is urgent to develop non-dioxygen dependent PDT agent [4]. Cellular levels of $\mathrm{H}_{2} \mathrm{O}_{2}$ directly or indirectly play a key role in malignant transformation and in sensitizing cancer cells to death. During the overexpression of $\mathrm{H}_{2} \mathrm{O}_{2}$ detoxifying enzymes or catalase in vivo, $\mathrm{H}_{2} \mathrm{O}_{2}$ concentration was expected to decrease, and the cancer cells reverted to normal appearance [5]. Cancer cells are more susceptible to $\mathrm{H}_{2} \mathrm{O}_{2}$ induced cell death than are normal cells. $\mathrm{Mn}$ (II) complexes of $\mathrm{N}$ substituted di(picolyl)amines have been reported as mimics of catalase. For example, manganese(II) complexes of $\mathrm{N}$-substituted di(picolyl)amines have been found to be multifunctional complexes that could act as mimics of catalase that inhibit the proliferation of cancer cells by attenuating the absorption of $\mathrm{Ca}^{2+}$ in mitochondria as well as disproportionation of $\mathrm{H}_{2} \mathrm{O}_{2}$ [6]. Recently, we found that $\left[\mathrm{Mn}(\mathrm{Adpa})(\mathrm{Cl})\left(\mathrm{H}_{2} \mathrm{O}\right)\right]$ (Adpa=bis(pyridyl-methyl)amino-2propionic acid) exhibited anti-proliferative and cytotoxic activity against diverse tumor types in vitro, as well as against tumor xenografts mediated by the ROS-dependent apoptotic and autophagic cell death [7]. Hence, $\mathrm{Mn}$ (II) complexes could be $\mathrm{H}_{2} \mathrm{O}_{2}$ activated anticancer 
complexes. $\mathrm{H}_{2} \mathrm{O}_{2}$-activatable and $\mathrm{O}_{2}$-evolving complexes could be used as clinical therapy agents in hypoxic environments.

Boradiazaindacenes (BODIPY) are very popular fluorophores with high quantum yields, longwavelength absorption and fluorescence emission in the visible spectral region [8]. BODIPY derivatives are used as fluorescence tags and probes which function in water or organic solvent, and near-IR absorbing BODIPY derivatives can be glutathione-activated photosensitizers for photodynamic therapy [9]. Previously, we found that BODIPY based cobalt(II) complexes could react with water to generate ${ }^{1} \mathrm{O}_{2}$ using water as the oxygen source [10]. It is therefore possible that $\mathrm{Mn}(\mathrm{II})$ complexes of BODIPY can be light activated anticancer agents. Graphene oxide (GO) is a combination of $\mathrm{sp}^{2}$ and $\mathrm{sp}^{3}$ hybridized carbon atoms and has remarkable optical properties. Hydrophobic organic compounds have been loaded on to the functional GO via stacking and hydrophobic interactions to increase the specific target to breast cancer cells [11]. Thus, the assembly of GO with photoactive $\mathrm{Mn}$ (II) complexes could increase the cancer target. Here, we report the LED light driven water oxidation and anticancer property of $\left[(\mathrm{BDA}) \mathrm{MnCl}_{2}\right]\left(\mathrm{Mn}_{1}\right)$ and its loaded graphene oxide $\left(\mathrm{Mn}_{1} @ \mathrm{GO}\right)$ (BDA = 8-[di(2-picolyl)amine-3-benzyl]-4,4-difluoro1,3,5,7-tetramethyl-4-bora-3a,4a-diaza-s-indacen)) (Scheme 1).

(Scheme 1)

\section{Experimetal section}

\subsection{Materials and methods.}

8-[Di(2-picolyl)amine-3-benzyl]-4,4-difluoro-1,3,5,7-tetramethyl-4-bora-3a,4a-diaza-sindacene (BDA) was synthesized as reported [12]. The $\mathrm{C}, \mathrm{H}$ and $\mathrm{N}$ microanalyses were 
performed on a Vario EL elemental analyzer. The metal analysis was recorded on TAS-986 atomic absorption spectrophotometer. Electronic absorption spectra were recorded in the 900$190 \mathrm{~nm}$ region using a Varian CARY 50-BIO UV-VIS spectrophotometer. Infrared spectra were recorded on a Nicolet-470 spectrophotometer in the wavenumber range of $4000-400 \mathrm{~cm}^{-1}$ using $\mathrm{KBr}$ pellets. Fluorescence measurements were performed on a fluorescence spectrofluorometer Model CARY Eclipse (VARIAN, USA), a $1.0 \mathrm{~cm}$ quartz cell $(\mathrm{ex}=460 \mathrm{~nm}$, slit width $=5$ $\mathrm{nm}$ ).The electrospray mass spectra (ES-MS) were determined on a Finnigan LCQ mass spectrograph. TEM was performed at room temperature on a JEOL JEM-200CX transmission electron microscope using an accelerating voltage of $200 \mathrm{kV}$. The EPR spectra of complexes in $\mathrm{CH}_{3} \mathrm{CN}$ were acquired at $298 \mathrm{~K}$ with a $0.201 \mathrm{~mW}$ power, $0.5 \mathrm{G}$ modulation amplitude, and 100 $\mathrm{kHz}$ modulation frequency. The volume of $\mathrm{O}_{2}$ was measured by direct methods, via connecting of the reaction vessel with a U-tube to a calibrated microburet with collection of the gas released. Oxygen evolution was monitored by gas chromatography using a thermal conductivity detector (GC-TCD).

\subsection{Synthesis of [(BDA)MnCl $]\left(M n_{1}\right)$}

A solution of BDA (100 mg, $0.186 \mathrm{mmol})$ in $15 \mathrm{ml} \mathrm{C}_{2} \mathrm{H}_{5} \mathrm{OH}$ was mixed with $\mathrm{MnCl}_{2} \cdot 4 \mathrm{H}_{2} \mathrm{O}$ (37 mg, $0.186 \mathrm{mmol}$ ).The mixture was refluxed for $2 \mathrm{~h}$ at $70^{\circ} \mathrm{C}$, and then it was cooled to room temperature to give brown red solution. After recrystallized with $\mathrm{CH}_{3} \mathrm{CH}_{2} \mathrm{OCH}_{2} \mathrm{CH}_{3}-\mathrm{CH}_{3} \mathrm{CN}$ (1:1), red solid (103 mg) was obtained yield 84\%. Found: C, 57.89; H, 4.85; N, 10.58, Mn, 8.24. Calcd. (\%) for $\mathrm{C}_{32} \mathrm{H}_{32} \mathrm{BCl}_{2} \mathrm{MnF}_{2} \mathrm{~N}_{5}$ : C, 58.12; H, 4.88; N, 10.59, Mn 8.31. UV-vis $\left(\mathrm{CH}_{3} \mathrm{CN} / \mathrm{nm}\right.$ ) $\left(\varepsilon \times 10^{-4}, \mathrm{M}^{-1} \mathrm{~cm}^{-1}\right): 231(3.2), 262(1.6), 315$ (1.1), 362(1.1), 498 (7.7). IR(KBr, $\left.v / \mathrm{cm}^{-1}\right): 3391 \mathrm{~m}$, 2963-2923 m, 1605 m, 1543 s, 1303 s, 1195 s, 981 s, 747 m. The metal analysis and elemental 
analysis indicate that the ratio of ligand (BDA): metal in $\mathrm{Mn}_{1}$ is $1: 1$. The thermal analysis (TG) curve of $\mathrm{Mn}_{1}$ in the range $0-1000{ }^{\circ} \mathrm{C}$ is shown in Fig. $\mathrm{S} 1$. The main peak for $\mathrm{Mn}_{1}$ in $\mathrm{MeCN}$ $\mathrm{m} / \mathrm{z}(\%)=625.27(100)$ corresponds to the species $[(\mathrm{BDA}) \mathrm{MnCl}]^{+}(\mathrm{Fig} . \mathrm{S} 2)$.

\subsection{Synthesis of $M n_{1} @ G O(G O=$ Graphene oxide $)$}

GO (2 mg) was dispersed to water $(2 \mathrm{~mL})$ resulting a dispersed solution of $\mathrm{GO}(2 \mathrm{mg} / \mathrm{mL})$. The dispersed solution of GO $(2 \mathrm{~mL}, 2 \mathrm{mg} / \mathrm{mL})$ was added to the solution $\left(3 \mathrm{~mL}, \mathrm{H}_{2} \mathrm{O}\right.$ : DMSO = 9:1) of $\mathrm{Mn}_{1}(100 \mu \mathrm{M})$. After the mixture was vigorously shaken for $1.5 \mathrm{~h}$ at room temperature, $\mathrm{CH}_{3} \mathrm{CN}(5 \mathrm{~mL})$ was added to precipitate the product. After centrifugation, the precipitate was washed with $\mathrm{CH}_{3} \mathrm{CN}$ to remove the free $\mathrm{Mn}_{1}$. The product $\mathrm{Mn}_{1} @ \mathrm{GO}$ was obtained after it was dried in vacuum.

\subsection{Cytotoxicity testing}

The cytotoxicity assays were measured with HepG-2 cells in normal culture conditions. HepG2 cells were seeded at adensity of $4 \times 10^{4}$ cells $\mathrm{ml}^{-1}$ into sterile 96-well plates. The complex $\mathrm{Mn}_{1}$ and $\mathrm{Mn}_{1} @ \mathrm{GO}$ were added in DMSO and diluted with culture media. After $24 \mathrm{~h}, \mathrm{Mn}_{1}$ and $\mathrm{Mn}_{1} @ \mathrm{GO}$ were added into the cultured HepG-2 cells for $24 \mathrm{~h}$. Cell viability was determined by the 3-[4,5-dimethylthiazol-2-yl]-2,5-diphenpyltetra-zolium bromide (MTT) assay measuring the absorbance at $570 \mathrm{~nm}$. Each test was performed in triplicate. Morphological change of HepG-2 cells was taken using Nikon Ti-E2000 microscope with live cell system.

\subsection{Cell morphological changes}

The morphological changes of the $\mathrm{H}_{2} \mathrm{~B}$-GFP-labeled HepG-2 cells were observed under a Nikon TE2000 microscope (Nikon, Tokyo, Japan) with a live cell system (LCS) which can 
provide $\mathrm{CO}_{2}$, temperature control and position fixing. The $\mathrm{H}_{2} \mathrm{~B}-\mathrm{GFP}-\mathrm{labeled} \mathrm{HepG}-2$ cells, which were incubated with materials, were observed for $24 \mathrm{~h}$. The bright and fluorescence imaginations of the cells were recorded and analyzed.

\subsection{Measurement of intracellular ROS production}

The intracellular generation of ROS was analyzed using the probe, DCFH-DA. Cells were incubated with $10 \mu \mathrm{M}$ DCFH-DA at $37{ }^{\circ} \mathrm{C}$ for $15 \mathrm{~min}$. The DCF fluorescence distribution of

$1 \times 10^{4}$ cells was then measured by fluorescence spectrometry (Spectra Max Gemini; Molecular Devices Corp.).

\subsection{Mitochondrial imaging}

HepG-2 cells were cultured in RPMI-1640 medium and DMEM medium (Gibco, USA), supplemented with $10 \%(\mathrm{v} / \mathrm{v})$ heat-inactivated fetal bovine serum and antibiotics (100 U. . $\mathrm{ml}^{-1}$ penicillin and $100 \mathrm{U} \cdot \mathrm{ml}^{-1}$ streptomycin) at $37{ }^{0} \mathrm{C}$ in a humidified atmosphere of $5 \%$ $\mathrm{CO}_{2}$. HepG-2 cells $\left(2.4 \times 10^{4}\right)$ were seeded into 24 -well plates (every plate was $\left.100 \mathrm{ml}\right)$ for $24 \mathrm{~h}$. Complexes were dissolved in DMSO and diluted with culture media then added and incubated for $1 \mathrm{~h}$. Next, the cells were dyed with $1 \mathrm{mg} \cdot \mathrm{ml}^{-1}$ MitoTracker Red FM (Molecular Probes Corporation, USA) for another $1 \mathrm{~h}$. Cell imaging of HepG-2 cells was conducted using a Nikon Ti-E 2000 microscope with live cell system (LCS) which can provide $\mathrm{CO}_{2}$, temperature control and position fixing. The brightness and fluorescence imaging of cells were recorded.

2.8 JC-1 staining to measure mitochondrial membrane potentials (MMP) 
MMP was determined using the fluorescent dye JC-1. HepG-2 cells were seeded in 96-well plates or on chamber slides and treated with complexes at the indicated concentrations and times. Fluorescence intensity was measured immediately following JC-1 staining $\left(5 \mathrm{mg} \cdot \mathrm{mL}^{-1}\right.$ of JC-1 at $37^{\circ} \mathrm{C}$ for $30 \mathrm{~min}$ ) by fluorescence spectrometry (Molecular Devices Corporation, USA) or observed using a fluorescence microscope (excitation $488 \mathrm{~nm} /$ emission $595 \mathrm{~nm}$ for JC-1 red).

\subsection{Western blot analysis on expression level of HIF-1 $\alpha$ in HepG-2 cells}

Proteins were extracted in lysis buffer (30 mM Tris, $\mathrm{pH} 7.5,150 \mathrm{mM}$ sodium chloride, $1 \mathrm{mM}$ phenylmethanesulfonyl fluoride, $1 \mathrm{mM}$ sodium orthovanadate, $1 \%$ Nonidet P-40, $10 \%$ glycerol, and phosphatase and protease inhibitors), separated by SDS-PAGE and transferred onto polyvinylidene fluoride membranes. The membranes were probed with antibodies (HIF-1 $\alpha$ and $\beta$-actin) overnight at $4^{\circ} \mathrm{C}$, and then incubated with a horse radish peroxidase-coupled secondary antibody. Detection was performed using a LumiGLO chemiluminescent substrate system [Kirkegaard \& Perry Laboratories, Inc. (KPL), Gaithersburg, MD, USA].

\section{Results and Discussions}

\subsection{Photophysical properties of $M n_{1}$ and $M n_{1} @ G O$.}

The UV spectra of $\mathrm{Mn}_{1}$ had bands at 230, 265, 315, 360, $460 \mathrm{~nm}$ and $499 \mathrm{~nm}$ (Fig. 1). The band at $460 \mathrm{~nm}$ and $499 \mathrm{~nm}$ can be attributed to the $\pi-\pi^{*}$ transition of the BODIPY structure. The wider band at $315 \mathrm{~nm}$ and $360 \mathrm{~nm}$ in $\mathrm{Mn}_{1}$ confirms the metal-ligand charge transfer interaction. The fluorescence spectrum of $\mathrm{Mn}_{1}$ presents a strong emission at $508 \mathrm{~nm}$ when excited at $460 \mathrm{~nm}$ (Fig. 2). The positive charged complex $\mathrm{Mn}_{1}$ can interact with GO via 
electrostatic and $\pi-\pi$ stacking. Adding GO to the solution of $\mathrm{Mn}_{1}$ leads to the decreased emission at $508 \mathrm{~nm}$ until the emission quenched completely when the ratio of $\mathrm{Mn} 1$ and GO is $1 \mu \mathrm{M}: 5 \mu \mathrm{g}$ ( $1 \mathrm{mM} \mathrm{Mn} \mathrm{M}_{1} / \mathrm{g} \mathrm{GO}$ ). The band at $499 \mathrm{~nm}$ of $\mathrm{Mn}_{1} @ \mathrm{GO}$ can be attributed to the $\pi-\pi^{*}$ transition of BODIPY structure, indicating that $\mathrm{Mn}_{1}$ has been combined to GO successfully. According to the TEM image of $\mathrm{Mn}_{1} @ \mathrm{GO}$, we found that $\mathrm{Mn}_{1}$ was wrapped in $\mathrm{GO}$ and nanospheres with the size of ca. 120-220 nm were formed (Fig. 3).

Fig. 1. UV spectra of BDA (a, $10 \mu \mathrm{M}), \mathrm{Mn}_{1}(\mathrm{~b}, 10 \mu \mathrm{M}), \mathrm{GO}\left(\mathrm{c}, 28 \mu \mathrm{g} \cdot \mathrm{mL}^{-1}\right)$ and $\mathrm{Mn}_{1} @ \mathrm{GO}\left(\mathrm{d}, \mathrm{C}_{\mathrm{Mn} 1} 6 \mu \mathrm{M}\right.$, $\left.\mathrm{C}_{\mathrm{GO}} 30 \mu \mathrm{g} \cdot \mathrm{mL}^{-1}\right)$ in $\mathrm{MeCN}-\mathrm{H}_{2} \mathrm{O}(\mathrm{v}: \mathrm{v}=2: 1)$.

Fig. 2. Fluorescence spectra of $\mathrm{Mn}_{1}(1.5 \mu \mathrm{M}$, DMSO) in the presence of various amount of GO $\left(\mathrm{m}_{\mathrm{GO}}=0,20,40,60,80,100,120,140,160,180 \mu \mathrm{g}\right)$. The excitation wavelength was $460 \mathrm{~nm}$.

Fig.3.TEM image of GO (left) and $\mathrm{Mn}_{1} @ \mathrm{GO}$ (right).

\subsection{Water oxidation catalyzed by $M n_{1}$}

The complex catalyzed water oxidation was confirmed by measuring the green LED light (500-600 nm, $10 \mathrm{w}$ ) irradiated due to the oxygen evolution. The obvious oxygen bubble could be observed when the complex $\mathrm{Mn}_{1}$ was added to $\mathrm{H}_{2} \mathrm{O}$ solution (Fig. 4, Table S1) while $\mathrm{Mn}_{1} @ \mathrm{GO}$ showed little activity of water oxidation. The complex was active at $\mathrm{pH} 7.2$ with the turnover frequency (TOF) of $\mathrm{Mn}_{1} 22.68 \mathrm{~h}^{-1}$. When the reaction was carried out in dark, nearly no oxygen evolution could be monitored, and we deduced that the reaction was light driven oxidation of water. The initial rate was measured as function of catalyst $\mathrm{Mn}_{1}$ concentration. The initial rate of 
$\mathrm{O}_{2}$ evolution was plotted as a function of the concentration of $\mathrm{Mn}_{1}$ giving a first-order rate constant $\mathrm{k}_{1}$ of $0.027 \pm 0.002 \mathrm{~min}^{-1}$ at $25^{\circ} \mathrm{C}, \mathrm{pH} 7.2$ (Fig. 4 b).

Fig.4. a) $\mathrm{O}_{2}$ production from an aqueous solution containing $\mathrm{Mn}_{1}(2 \mathrm{mg})$ under green LED light $(500-600 \mathrm{~nm}$, $10 \mathrm{~W}$ ) at different $\mathrm{pH}\left(\right.$ 斿, aqueous phosphate buffer $(\mathrm{PB})$ solution, $\mathrm{pH} 7.2 ; \diamond, \mathrm{H}_{2} \mathrm{O} ; \boldsymbol{\Delta}, \mathrm{PB}$ solution, $\mathrm{pH} 8.5 ; \circ$, PB solution, $\mathrm{pH} 4.0$ ); b) The initial rate of $\mathrm{O}_{2}$ evolution plotted as a function of the concentration of $\mathrm{Mn}_{1}$. Slop $=0.027 \pm 0.002 \mathrm{~min}^{-1}, \mathrm{R}^{2}=0.980$.

The interaction of $\mathrm{Mn}_{1}$ and water was monitored by UV-vis spectroscopy (Fig. S3). A new absorbance at $560 \mathrm{~nm}$ emerged when $\mathrm{Mn}_{1}$ was titrated with water. This suggested that the reaction of $\mathrm{Mn}_{1}$ with $\mathrm{H}_{2} \mathrm{O}$ could result in the formation of oxidized complex intermediates. Recycled $\mathrm{Mn}_{1}$ was obtained after $\mathrm{Mn}_{1}$ reacted with water for $1 \mathrm{~h}$, centrifuged and dried in vacuum. The EPR spectra of recycled $\mathrm{Mn}_{1}$ in $\mathrm{MeCN}$ show multiline EPR signals at $\mathrm{g}=4.1$ indicating existence of $\mathrm{Mn}^{\mathrm{III}}$ or $\mathrm{Mn}^{\mathrm{IV}}$ (Fig. 5) [13]. Hence, we deduce that the in-site formed $\mathrm{Mn}^{\mathrm{III}}$ or $\mathrm{Mn}^{\mathrm{IV}}$ intermediates can work as electron acceptors because $\mathrm{Mn}_{1}$ can catalyze water oxidation without extra electron acceptors. For water oxidation, the recycled $\mathrm{Mn}_{1}$ is less active than $\mathrm{Mn}_{1}$. Only $\mathrm{Mn}_{1}-\mathrm{H}_{2} \mathrm{O}$ system is a dioxygen generator.

Fig. 5. X-Band EPR spectrum of recycled $\mathrm{Mn}_{1}$ in $\mathrm{MeCN}$

\subsection{Electrochemical properties.}

In dry MeCN solution at a pt electrode, the $\mathrm{Mn}_{1}$ displays one irreversible $\mathrm{Mn}^{\mathrm{III}} / \mathrm{Mn}^{\mathrm{II}}$ couple at $\mathrm{E}_{1 / 2}=-0.3 \mathrm{~V}$ and one quasi-reversible redox couple at $1.62 \mathrm{~V}$, which can be assigned to the 
oxidation of ligand (Figure S4). The $\mathrm{Mn}_{1} @ \mathrm{GO}$ (dispersed in dry $\mathrm{MeCN}$ ) displays one irreversible redox peak at $-0.35 \mathrm{~V}$. With the addition of water, a reversible $\mathrm{Mn}^{\mathrm{V}} / \mathrm{Mn}^{\mathrm{IV}}$ wave at $1.05 \mathrm{~V}$ was observed for $\mathrm{Mn}_{1} @ \mathrm{GO}$ in $\mathrm{MeCN}: \mathrm{H}_{2} \mathrm{O}=6: 1$ solution (Fig. 6). This indicates that $\mathrm{Mn}_{1} @ \mathrm{GO}\left(\mathrm{Mn}^{2+}\right)$ can react with water resulting oxidized $\mathrm{Mn}_{1} @ \mathrm{GO}\left(\mathrm{Mn}^{\mathrm{n}+}, \mathrm{n}=\mathrm{IV}\right.$ or V) in electrochemical conditions. Moreover, titration of $\mathrm{Mn}_{1} @ \mathrm{GO}$ with equal amount of $\mathrm{H}_{2} \mathrm{O}_{2}$ results oxidized $\mathrm{Mn}_{1} @ \mathrm{GO}$ (labeled as $\mathrm{Mn}_{1} @ \mathrm{GO} @ \mathrm{H}_{2} \mathrm{O}_{2}$ ). The redox peak at $0.51 \mathrm{~V}$ indicates the main species for $\mathrm{Mn}_{1} @ \mathrm{GO} @ \mathrm{H}_{2} \mathrm{O}_{2}$ in $\mathrm{MeCN}-\mathrm{H}_{2} \mathrm{O}$ (1:1) solution are $\mathrm{Mn}^{\mathrm{IV}} / \mathrm{Mn}^{\mathrm{III}}$ couples (Fig. S5). Electrochemical data confirm that $\mathrm{Mn}_{1} @ \mathrm{GO}$ can react with $\mathrm{H}_{2} \mathrm{O}_{2}$ resulting oxidized manganese species.

Fig. 6. Cyclic voltammetry curves of solutions of $\mathrm{Mn}_{1} @ \mathrm{GO}\left(\mathrm{C}_{\mathrm{Mn}}, 1 \mathrm{mM}\right)$ in dry $\mathrm{MeCN}$ (black line), $\mathrm{Mn}_{1} @ \mathrm{GO}$ in $\mathrm{MeCN}: \mathrm{H}_{2} \mathrm{O}=6: 1$ (dashed line) at $298 \mathrm{~K}$ (vs SCE), platinum working electrode, $100 \mathrm{mV} / \mathrm{s} \mathrm{scan}$ rate.

\subsection{Cytotoxicity assay}

$\mathrm{Mn}_{1}$ and $\mathrm{Mn}_{1} @ \mathrm{GO}$ were studied for their antitumor activity in vitro by determining their inhibition against growth of HepG-2 cells using the method of MTT reduction. Both $\mathrm{Mn}_{1}$ and $\mathrm{Mn}_{1} @ \mathrm{GO}$ were active against HepG-2 cells in dose dependent manner with $\mathrm{IC}_{50}$ values of 10.45 $\mu \mathrm{M}\left(\mathrm{C}_{\mathrm{Mn} 1}\right)$ and $10.14 \mu \mathrm{M}\left(\mathrm{C}_{\mathrm{Mn} 2+}\right)$, respectively (Fig. 7$)$. To explore the anticancer activity for $\mathrm{Mn}_{1}$ and $\mathrm{Mn}_{1} @ \mathrm{GO}$ in hypoxic conditions, the HepG-2 cells were incubated with $\mathrm{CoCl}_{2}(200 \mu \mathrm{M})$ for $24 \mathrm{~h}$, and then cell viability was examined by MTT. It is found that $\mathrm{Mn}_{1} @ \mathrm{GO} @ \mathrm{H}_{2} \mathrm{O}_{2}\left(\mathrm{C}_{\mathrm{Mn} 2+}\right.$, $4 \mu \mathrm{M})$ show good inhibition on $\mathrm{CoCl}_{2}$ treated HepG-2 cells, the inhibition for $\mathrm{Mn}_{1}$ and $\mathrm{Mn}_{1} @ \mathrm{GO}$ on the proliferation of $\mathrm{CoCl}_{2}$ treated HepG-2 cells is dependent on their 
concentrations (Fig. S6). This indicates that dioxygen concentration has great effect on the anticancer activities of $\mathrm{Mn}_{1}$ and $\mathrm{Mn}_{1} @ \mathrm{GO}$. Cellular levels of $\mathrm{H}_{2} \mathrm{O}_{2}$ directly or indirectly play a key role in malignant transformation and sensitizing cancer cells to death [5]. Cancer cells are more susceptible to $\mathrm{H}_{2} \mathrm{O}_{2}$ induced cell death than normal cells are. $\mathrm{H}_{2} \mathrm{O}_{2}$ is considered to be a mediator of apoptotic cell death [14]. Based on the reaction of $\mathrm{Mn}_{1} @ \mathrm{GO}$ with $\mathrm{H}_{2} \mathrm{O}_{2}$, we deduce that $\mathrm{Mn}_{1} @ \mathrm{GO}$ can be as potential $\mathrm{H}_{2} \mathrm{O}_{2}$ activated anticancer materials.

Fig. 7. Inhibition activities of $\mathrm{Mn}_{1}$ and $\mathrm{Mn}_{1} @ \mathrm{GO}$ on the proliferation of HepG-2 cells. HepG-2 cells without compounds were used as controls.

To study whether $\mathrm{Mn}_{1}$ and $\mathrm{Mn}_{1} @ \mathrm{GO}$ could be used as photo-activated anticancer agents, HepG-2 cells were treated with $\mathrm{Mn}_{1}(1 \mu \mathrm{M})$ or $\mathrm{Mn}_{1} @ \mathrm{GO}\left(\mathrm{C}_{\mathrm{Mn} 1}, 1 \mu \mathrm{M}\right)$ in dark and green LED light irradiated conditions, and the cells were analyzed (Fig. S7). The HepG-2 cells without drugs were used as the control. $\mathrm{Mn}_{1}(1 \mu \mathrm{M})$ or $\mathrm{Mn}_{1} @ \mathrm{GO}\left(\mathrm{C}_{\mathrm{Mn} 1}, 1 \mu \mathrm{M}\right)$ was used since it showed nearly no inhibition on the proliferation of HepG-2 cells in the dark so that every inhibition may be due to its activation upon the irradiation of the LED light. Control experimental results showed HepG-2 cells show nearly no cell shrinkage when irradiated by green LED (10 w) light for 15 min. We also found that both $\mathrm{Mn}_{1}(1 \mu \mathrm{M})$ or $\mathrm{Mn}_{1} @ \mathrm{GO}\left(\mathrm{C}_{\mathrm{Mn} 1}, 1 \mu \mathrm{M}\right)$ could cause obvious death of HepG-2 cells when irradiated for 15 min, while cells showed normal morphology when treated with $\mathrm{Mn}_{1}(1 \mu \mathrm{M})$ or $\mathrm{Mn}_{1} @ \mathrm{GO}\left(\mathrm{C}_{\mathrm{Mn} 1}, 1 \mu \mathrm{M}\right)$ without green LED light. This result demonstrates that both $\mathrm{Mn}_{1}(1 \mu \mathrm{M})$ and $\mathrm{Mn}_{1} @ \mathrm{GO}\left(\mathrm{C}_{\mathrm{Mn} 1}, 1 \mu \mathrm{M}\right)$ could act as potential photoactivated anticancer agents. The LED light enhanced anticancer property for $\mathrm{Mn}_{1}$ may be due to the ability of $\mathrm{Mn}_{1}$ to catalyze the water oxidation with the generation of dioxygen thereby 
increasing the amount of oxygen in the cell. This increased oxygen lead to increased amount of singlet oxygen $\left({ }^{1} \mathrm{O}_{2}\right), \cdot \mathrm{OH}$ and other intermediates when LED light was incident on $\mathrm{Mn}_{1}$, which could induce cell death and oxidative stress. This was confirmed by the high ROS production (Fig. 8) which may induce apoptotic cell death. This shows that the amount of the oxygen in the cancer cells plays a critical role in the photosensitization therapy.

From Fig. 8, though both $\mathrm{Mn}_{1}$ and $\mathrm{Mn}_{1} @ \mathrm{GO}$ exerted antitumor activity through production of high concentration of ROS when irradiated, the ROS produced by $\mathrm{Mn}_{1}$ was about two times that of $\mathrm{Mn}_{1} @ \mathrm{GO}$. This suggests that conversion of $\mathrm{H}_{2} \mathrm{O}_{2}$ into oxygen plays very important role in the ROS production during the light irradiation. $\mathrm{Mn}_{1} @ \mathrm{GO}$ showed little activity in the oxygen production therefore depended on the only oxygen in cell for the sensitization thereby inducing lower amount of ROS. $\mathrm{Mn}_{1} @ \mathrm{GO}$ can react with $\mathrm{H}_{2} \mathrm{O}_{2}$ with the emission at $508 \mathrm{~nm}$ partially recovered (Fig. S8) and $\mathrm{Mn}_{1} @ \mathrm{GO}$ mixed with $\mathrm{H}_{2} \mathrm{O}_{2}$ in water resulting in $\mathrm{Mn}_{1} @ \mathrm{GO} @ \mathrm{H}_{2} \mathrm{O}_{2}$, which have a redox peak at $0.51 \mathrm{~V}$ indicating the existence of the $\mathrm{Mn}^{\mathrm{IV}} / \mathrm{Mn}^{\mathrm{III}}$ species in $\mathrm{Mn}_{1} @ \mathrm{GO} @ \mathrm{H}_{2} \mathrm{O}_{2}$. EPR data of $\mathrm{Mn}_{1} @ \mathrm{GO} @ \mathrm{H}_{2} \mathrm{O}_{2}$ nanoparticles show the multiline EPR signals at $\mathrm{g}=4.6$ (Fig. S9). These indicate that $\mathrm{Mn}_{1} @ \mathrm{GO}$ may react with $\mathrm{H}_{2} \mathrm{O}_{2}$ and produce intermediates $\mathrm{Mn}_{1} @ \mathrm{GO} @ \mathrm{H}_{2} \mathrm{O}_{2}$, which show high inhibition on both HepG-2 cells and $\mathrm{CoCl}_{2}-$ treated signaling HepG-2 cells. The reaction of $\mathrm{Mn}_{1} @ \mathrm{GO}$ and $\mathrm{H}_{2} \mathrm{O}_{2}$ with the formation of $\mathrm{Mn}_{1} @ \mathrm{GO} @ \mathrm{H}_{2} \mathrm{O}_{2}$ can be accelerated by LED light. Thus, the anticancer of $\mathrm{Mn}_{1} @ \mathrm{GO}$ also can be enhanced by LED light. Above all, $\mathrm{Mn}_{1} @ \mathrm{GO}$ can be LED light enhanced anticancer materials in hypoxic environments.

Fig. 8. Effect on the ROS content in HepG-2 for $\mathrm{Mn}_{1}(1 \mu \mathrm{M})$ and $\mathrm{Mn}_{1} @ \mathrm{GO}\left(\mathrm{C}_{\mathrm{Mn} 1}, 1 \mu \mathrm{M}\right)$.

\subsection{Target mitochondrial and effect on the expression of HIF}


The mitochondrial target imaging of $\mathrm{Mn}_{1}$ was assessed by comparison with Mito Tracker Red FM. MitoTracker Red FM binds to lipids in mitochondria membranes. HepG-2 cells were incubated with $\mathrm{Mn}_{1}(10 \mu \mathrm{M})$ for $60 \mathrm{~min}$ at $37{ }^{\circ} \mathrm{C}$, then MitoTracker Red FM $\left(1 \mathrm{mg} \cdot \mathrm{mL}^{-1}\right)$ was added, and the cell images were recorded. The green fluorescence is overlapped with red emission of MitoTracker Red FM indicating that $\mathrm{Mn}_{1}$ can enter the mitochondrial in HepG-2 cell (Fig. 9). To examine whether the $\mathrm{Mn}_{1}$ and $\mathrm{Mn}_{1} @ \mathrm{GO}$ can affect mitochondrial function, mitochondrial membrane potential (MMP) was examined. The mitochondrial membrane potential was measured by adopting fluorescent probe JC-1 specifically labeled mitochondria. The changes in membrane potential were reflected by the ratio of red fluorescence $(595 \mathrm{~nm})$ and green fluorescence $(525 \mathrm{~nm}$ ) change of JC-1 (Fig.S10). Treatment with $0,1 \mu \mathrm{M}$ and $4 \mu \mathrm{M}$ of both $\mathrm{Mn}_{1}$ and $\mathrm{Mn}_{1} @ \mathrm{GO}$ for $36 \mathrm{~h}$ led to MMP collapse, showing reduced red intensity of JC- 1 . Results suggest that both $\mathrm{Mn}_{1}$ and $\mathrm{Mn}_{1} @ \mathrm{GO}$ can enter into negatively charged cells driven by the membrane potential. Cancer cells exhibit an extensive metabolic reprogramming that renders them more susceptible to mitochondrial perturbations [15]. Mitochondria of cancer cells are structurally and functionally different from normal cells such as molecular composition of the mitochondrial inner membrane and the occurrence of mitochondrial membrane permeabilization [16]. Dysfunction of mitochondrial involved in the apoptotic process and the energy metabolism of malignant cell [17]. Hence, we suggest that the good anticancer property of $\mathrm{Mn}_{1}$ and $\mathrm{Mn}_{1} @ \mathrm{GO}$ may be the dysfunction of mitochondria.

Fig. 9. Fluorescence image of $\mathrm{Mn}_{1}(10 \mu \mathrm{M})$ in HepG-2 cells. a: $\mathrm{Mn}_{1}$ imaging; b: MitoTracker Red FM imaging; c: Overlapped imaging of $\mathrm{Mn}_{1}$ and MitoTracker Red FM. 
Oxygen is an important factor to maintain cell life and the final electron acceptor in oxidative phosphorylation for energy production [18]. Hypoxia-inducible factor (HIF) regulates the energy metabolism by triggering a switch from mitochondrial oxidative phosphorylation to anaerobic glycolysis [19]. HIF is a common link between $\mathrm{O}_{2}$ availability, malignant progression, and changes in cancer metabolism. $\mathrm{Mn}_{1}$ can target mitochondria and react with $\mathrm{H}_{2} \mathrm{O}_{2}$ or water generating dioxygen, it may have some effect on the expression of HIF-1 $\alpha$ in HepG-2 cells. Experimental results show that the content of HIF-1 $\alpha$ decreased with the increased concentration of $\mathrm{Mn}_{1}$, and $30 \mu \mathrm{M}$ of $\mathrm{Mn}_{1}$ obviously decreases the expression of HIF-1 $\alpha$ in $24 \mathrm{~h}$ (Fig. 10). Therefore, this result demonstrates that $\mathrm{Mn}_{1}$ is a multifunctional complex to attenuate the expression of HIF-1 $\alpha$ in cancer cells.

Fig. 10. The expression of HIF-1 $\alpha$ in HepG-2 cells after incubated with different concentrations of $\mathrm{Mn}_{1}$ for $24 \mathrm{~h}$. Control (10 $\mu \mathrm{M}$ DMSO).

\section{Conclusions}

In normal conditions, both $\mathrm{Mn}_{1}$ and $\mathrm{Mn}_{1} @ \mathrm{GO}$ were active against HepG-2 cells, with $\mathrm{IC}_{50}$ values of $10.45 \mu \mathrm{M}$ and $10.14 \mu \mathrm{M}$ respectively. It was also found that both compounds could be used as photo-activated anticancer materials since $\mathrm{Mn}_{1}(1 \mu \mathrm{M})$ and $\mathrm{Mn}_{1} @ \mathrm{GO}\left(\mathrm{C}_{\mathrm{Mn} 1}, 1 \mu \mathrm{M}\right)$ were able to exhibit inhibition on the proliferation of HepG-2 cells when irradiated with green LED light. In particular, $\mathrm{Mn}_{1} @ \mathrm{GO}$ can react with $\mathrm{H}_{2} \mathrm{O}_{2}$ resulting active species, and work as $\mathrm{H}_{2} \mathrm{O}_{2}$ and light activated anticancer nanoparticles. Our results indicate that photoactive Mn(II) complexes loaded GO can be potential both light and $\mathrm{H}_{2} \mathrm{O}_{2}$ enhanced anticancer agents. In particular, 
$\mathrm{Mn}_{1} @ \mathrm{GO}$ can be LED light enhanced anticancer materials in hypoxic environments and $\mathrm{Mn}_{1}$ can target mitochondria and has some effect on the expression of HIF-1 $\alpha$ in HepG-2 cells. Therefore,

this result demonstrates that $\mathrm{Mn}_{1}$ is a multifunctional complex to attenuate the expression of HIF-1 $\alpha$ in cancer cells. Cancer cells use $\mathrm{O}_{2}$ to generate excessive levels of ROS and $\mathrm{H}_{2} \mathrm{O}_{2}$. $\mathrm{H}_{2} \mathrm{O}_{2}$-activatable and $\mathrm{O}_{2}$-evolving anticancer nanoparticles could be developed further as new kinds of cancer targeted anticancer agents.

\section{Acknowledgments}

Financial support from National Science Foundation of China (21271090, 21571085).

\section{Appendix A. Supplementary data}

Supplementary data to this article can be found online at http://dx.doi.org/10.1016/.

\section{References}

[1] (a) J.P. Celli, B.Q. Spring, I. Rizvi, C.L. Evans, K.S. Samkoe, S. Verma, B.W. Pogue, T. Hasan, Chem. Rev. 110 (2010) 2795-2838. (b) S. Yano, S. Hirohara, M. Obata, Y. Hagiya, S. Ogura, A. Ikeda, H. Kataoka, M. Tanaka, T, Joh, J. Photochem. Photobiol. C. 12 (2011) 46-67. (c) P.M. Antoni, A. Naik, I. Albert, R. Rubbiani, S. Gupta, P. Ruiz-Sanchez, P. Munikorn, J.M. Mateos, V. Luginbuehl, P. Thamyongkit, U. Ziegler, G. Gasser, G. Jeschke, B. Spingler, Chem. Eur. J. 21 (2015) 1179-1183.

[2] (a) B.W. Henderson, V.H. Fingar, Cancer Res. 47 (1987) 3110-3114. (b) H.C. Chen, J.W. Tian, W.J. He, Z.J. Guo, J. Am. Chem. Soc. 137 (2015) 1539-1547.

[3] (a) J.M. Brown, W.R. Wilson, Nat. Rev. Cancer. 4(2004) 437-447. (b) S.S. Lucky, K.C. Soo, Y. Zhang, Chem. Rev. 115 (2015) 1190-2042. 
[4] (a) J.F. Lovell, T.W.B. Liu. J. Chen, G. Zheng, Chem. Rev. 110 (2010) 2839-2857. (b) C.H. Wu, Q.H. He, A.N. Zhu, D. Li, M. Xu, H. Yang, Y.Y. Liu, ACS Appl. Mater. Interfaces 6 (2014) 21615-21623. (C) X. L. Tu, L. Wang, Y. H. Cao, Y.F. Ma, H. Shen, H. M. X. Zhang, Z. J. Zhang, Carbon 97 (2016) 35-44.

[5] M. López-Lázaro, Cancer Lett. 252 (2007) 1-8.

[6] (a) I.S. Turan, F.P. Cakmak, D.C. Yildirim, R. Cetin-Atalay, E.U. Akkaya, Chem. Eur. J. 20 (2014) 16088-16092. (b) Z.W. Wang, Q.Y. Chen, Q.S. Liu, Trans. Metal. Chem. 39 (2014) 917-924. (c) D.F. Zhou, Q.Y. Chen, Y. Qi, H.J. Fu, Z. Li, K.D. Zhao, J. Gao, Inorg. Chem. 50 (2011) 6929-6937. (c) Q.Y. Chen, D.F. Zhou, J. Huang, W.J. Guo, J. Gao, J. Inorg. Biochem. 104 (2010) 1141-1147.

[7] J. Liu, W.J. Guo, J. Li, X. Li, J. Geng, Q.Y. Chen, J. Gao, Int. J. Mol. Med. 35 (2015) 607616.

[8] S. Guo, L.H. Ma, J.Z. Zhao, B. Kuçukoz, A. Karatay, M. Hayvali, H.G. Yaglioglu, Chem. Sci. 5 (2014) 489-500.

[9] (a) C.C. Zhao, Y.F. Zhang, X.Z. Wang, J. Cao, J. Photochem. Photobiol. A: Chem. 264 (2013) 41-47. (b) A. Kamkaew, S.H. Lim,H.B. Lee, L.V. Kiew, L.Y. Chung, K. Burgess, Chem. Soc. Rev. 42 (2013) 77-88.

[10] Q.Y. Chen, M.Y. Kong, P.D. Wang, S.C. Meng, X.L. Xu, RSC Adv. 4(2014) 50693-50698.

[11] (a) Y.N. Ni, F.Y. Zhang, S. Kokot, Anal. Chim. Acta. 769 (2013) 40-48. (b) Y.Q. Xu, A. Malkovskiy, Y.A. Pang, Chem. Comm. 47 (2011) 6662-6664.

[12] Z. Li, Q.Y. Chen, P.D. Wang, Y. Wu, RSC Adv. 3 (2013) 5524-5528.

[13] P. Geijer, S. Peterson, K.A. Åhrling, Z. Deák, S. Styring, Biochim. Biophys. Acta. 1503 (2001) 83-95. 
[14] A.T.Y. Lau, Y.Wang, J.F. Chiu, J. Cell. Biochem. 104 (2008) 657-667.

[15] S.J. Ralph, S. Rodríguez-Enríquez, J. Neuzil, R. Moreno-Sánchez, Mol. Aspects Med. 31 (2010) 29-59.

[16] M. López-Lázaro, Mol. Med. 16 (2010) 144 -153.

[17] G.G.M. D’Souza, M.A. Wagle, V. Saxena, A. Shah, Biochem. Biophy. Acta 1807 (2011) 689-696.

[18] N. Dehne, G. Hintereder, B. Brüne, Exp. Cell. Res. 316 (2010) 1179-1189.

[19] N. God N, M. Kanai, Inter. J. Hematol. 95 (2012) 457-463. 
Figure captions

Scheme 1. The structure of BDA.

Fig. 1. UV spectra of BDA (a, $10 \mu \mathrm{M}), \mathrm{Mn}_{1}(\mathrm{~b}, 10 \mu \mathrm{M}), \mathrm{GO}\left(\mathrm{c}, 28 \mu \mathrm{g} \cdot \mathrm{mL}^{-1}\right)$ and $\mathrm{Mn}_{1} @ \mathrm{GO}(\mathrm{d}$, $\left.\mathrm{C}_{\mathrm{Mn} 1} 6 \mu \mathrm{M}, \mathrm{C}_{\mathrm{GO}} 30 \mu \mathrm{g} \cdot \mathrm{mL}^{-1}\right)$ in $\mathrm{MeCN}-\mathrm{H}_{2} \mathrm{O}(\mathrm{v}: \mathrm{v}=2: 1)$.

Fig. 2. Fluorescence spectra of $\mathrm{Mn}_{1}(1.5 \mu \mathrm{M}, \mathrm{DMSO})$ in the presence of various amount of GO $\left(\mathrm{m}_{\mathrm{GO}}=0,20,40,60,80,100,120,140,160,180 \mu \mathrm{g}\right)$. The excitation wavelength was $460 \mathrm{~nm}$.

Fig.3. TEM image of GO (left) and $\mathrm{Mn}_{1} @ \mathrm{GO}$ (right).

Fig.4. a) $\mathrm{O}_{2}$ production from an aqueous solution containing $\mathrm{Mn}_{1}(2 \mathrm{mg})$ under green LED light $(500-600 \mathrm{~nm}, 10 \mathrm{~W})$ at different $\mathrm{pH}($ 放, aqueous phosphate buffer $(\mathrm{PB})$ solution, $\mathrm{pH}$ 7.2;

$\mathrm{H}_{2} \mathrm{O} ; \boldsymbol{\Lambda}$, PB solution, $\mathrm{pH} 8.5$; $\circ, \mathrm{PB}$ solution, $\mathrm{pH} 4.0$ ); b) The initial rate of $\mathrm{O}_{2}$ evolution plotted as a function of the concentration of $\mathrm{Mn}_{1}$. Slop $=0.027 \pm 0.002 \mathrm{~min}^{-1}, \mathrm{R}^{2}=0.980$.

Fig. 5. X-Band EPR spectrum of recycled $\mathrm{Mn}_{1}$ in $\mathrm{MeCN}$.

Fig. 6. Cyclic voltammetry curves of solutions of $\mathrm{Mn}_{1} @ \mathrm{GO}\left(\mathrm{C}_{\mathrm{Mn}}, 1 \mathrm{mM}\right)$ in dry MeCN (black line), $\mathrm{Mn}_{1} @ \mathrm{GO}$ in $\mathrm{MeCN}: \mathrm{H}_{2} \mathrm{O}=6: 1$ (dashed line) at $298 \mathrm{~K}$ (vs SCE), platinum working electrode, $100 \mathrm{mV} / \mathrm{s}$ scan rate.

Fig. 7. Inhibition activities of $\mathrm{Mn}_{1}$ and $\mathrm{Mn}_{1} @ \mathrm{GO}$ on the proliferation of HepG-2 cells. HepG-2 cells without compounds were used as controls. 
Fig. 8. Effect on the ROS content in HepG-2 for $\mathrm{Mn}_{1}(1 \mu \mathrm{M})$ and $\mathrm{Mn}_{1} @ \mathrm{GO}\left(\mathrm{C}_{\mathrm{Mn} 1}, 1 \mu \mathrm{M}\right)$.

Fig. 9. Fluorescence image of $\mathrm{Mn}_{1}(10 \mu \mathrm{M})$ in HepG-2 cells. a: $\mathrm{Mn}_{1}$ imaging; b: MitoTracker Red FM imaging; c: Overlapped imaging of $\mathrm{Mn}_{1}$ and MitoTracker Red FM.

Fig. 10. The expression of HIF-1 $\alpha$ in HepG-2 cells after incubated with different concentrations of $\mathrm{Mn}_{1}$ for $24 \mathrm{~h}$. Control (10 $\mu \mathrm{M}$ DMSO). 


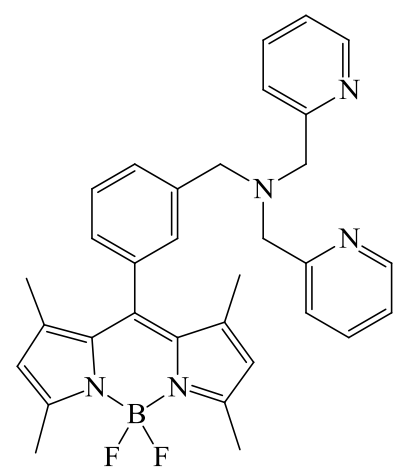

Scheme 1. The structure of BDA.

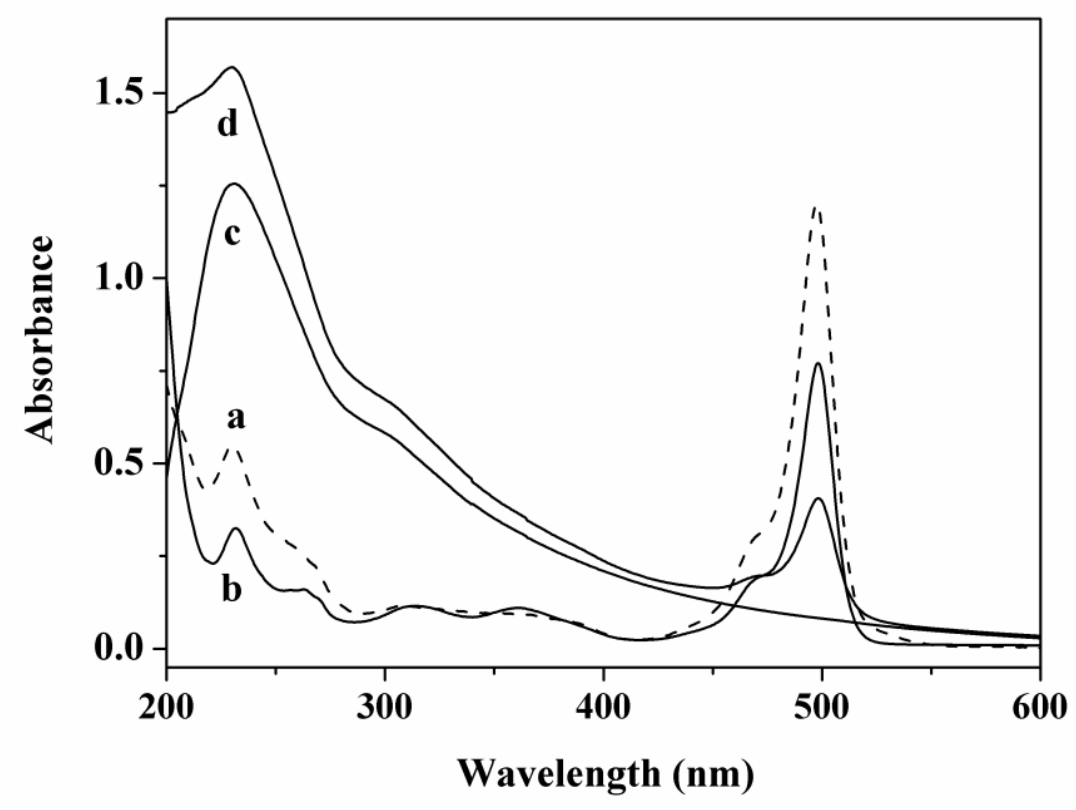

Fig. 1. UV spectra of BDA $(\mathrm{a}, 10 \mu \mathrm{M}), \mathrm{Mn}_{1}(\mathrm{~b}, 10 \mu \mathrm{M}), \mathrm{GO}\left(\mathrm{c}, 28 \mu \mathrm{g} \cdot \mathrm{mL}^{-1}\right)$ and $\mathrm{Mn}_{1} @ \mathrm{GO}(\mathrm{d}$, $\left.\mathrm{C}_{\mathrm{Mn} 1} 6 \mu \mathrm{M}, \mathrm{C}_{\mathrm{GO}} 30 \mu \mathrm{g} \cdot \mathrm{mL}^{-1}\right)$ in $\mathrm{MeCN}-\mathrm{H}_{2} \mathrm{O}(\mathrm{v}: \mathrm{v}=2: 1)$. 


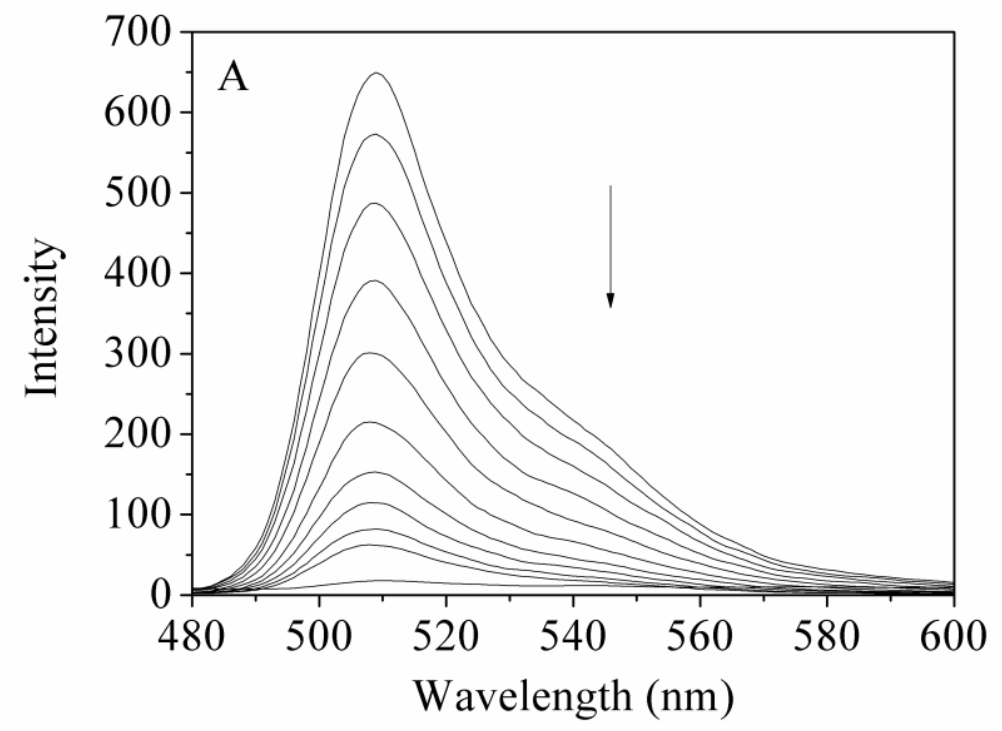

Fig. 2. Fluorescence spectra of $\mathrm{Mn}_{1}(1.5 \mu \mathrm{M}, \mathrm{DMSO})$ in the presence of various amount of $\mathrm{GO}(\mathrm{m}$ $\mathrm{GO}=0,20,40,60,80,100,120,140,160,180 \mu \mathrm{g})$. The excitation wavelength was $460 \mathrm{~nm}$.

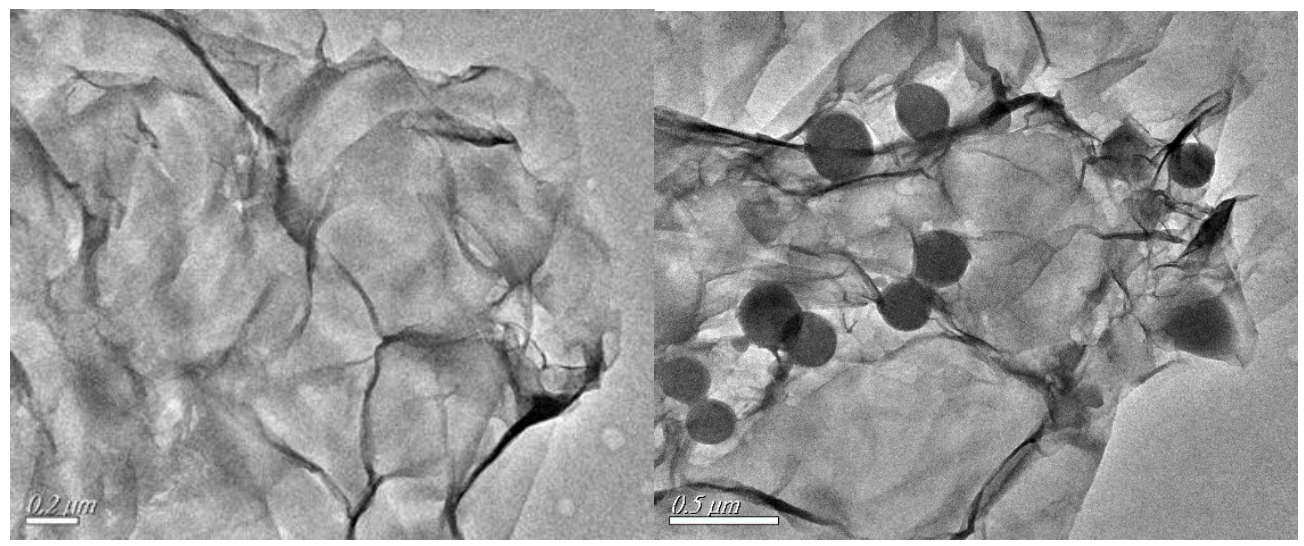

Fig.3. TEM image of GO (left) and $\mathrm{Mn}_{1} @ \mathrm{GO}$ (right). 

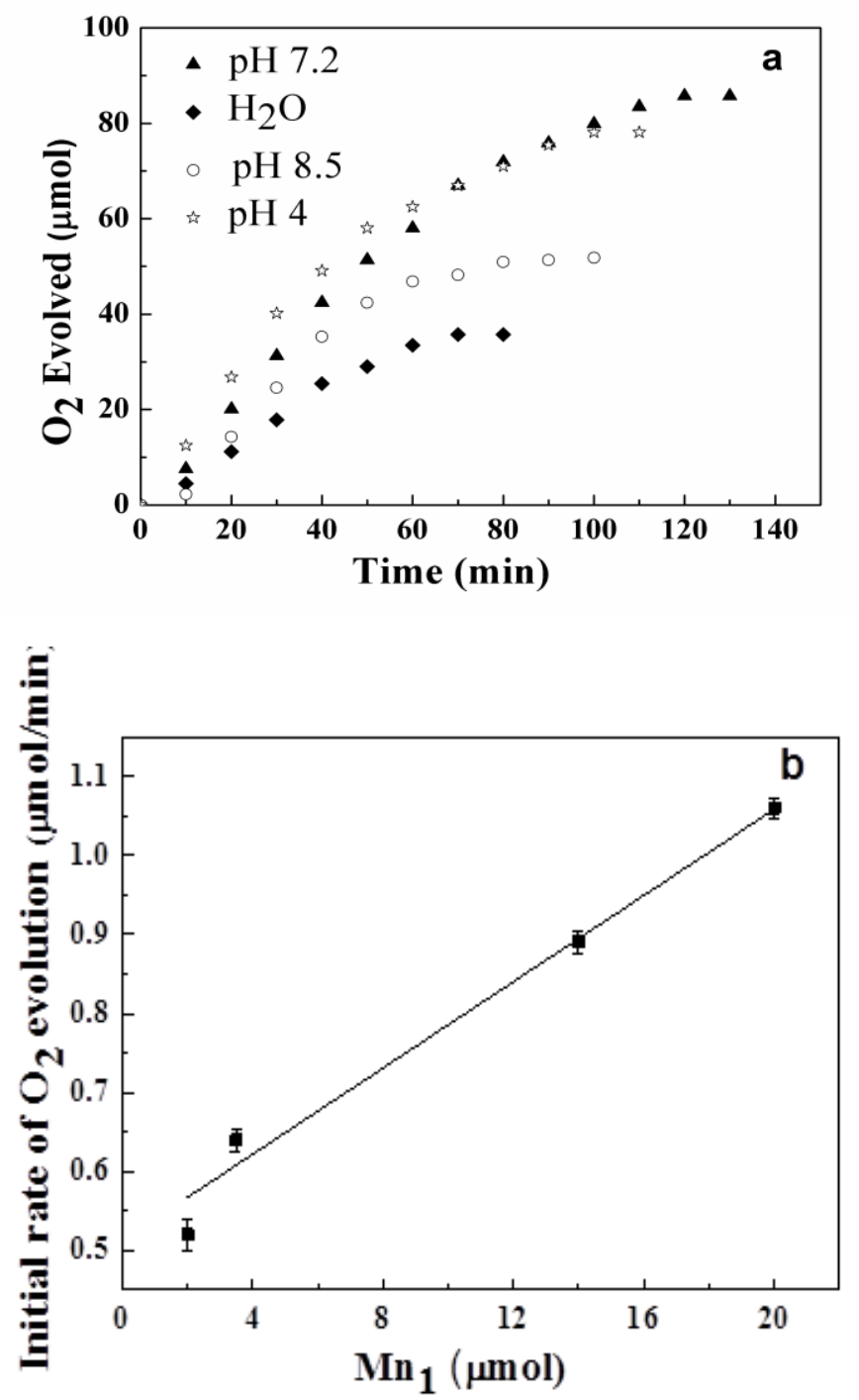

Fig.4. a) $\mathrm{O}_{2}$ production from an aqueous solution containing $\mathrm{Mn}_{1}(2 \mathrm{mg})$ under green LED $\operatorname{light}(500-600 \mathrm{~nm}, 10 \mathrm{~W})$ at different $\mathrm{pH}($ 汸, aqueous phosphate buffer $(\mathrm{PB})$ solution, $\mathrm{pH}$ 7.2;

$\mathrm{H}_{2} \mathrm{O} ; \boldsymbol{\Lambda}$, PB solution, $\mathrm{pH} 8.5$; $\circ, \mathrm{PB}$ solution, $\mathrm{pH} 4.0$ ); b) The initial rate of $\mathrm{O}_{2}$ evolution plotted as a function of the concentration of $\mathrm{Mn}_{1}$. Slop $=0.027 \pm 0.002 \mathrm{~min}^{-1}, \mathrm{R}^{2}=0.980$. 


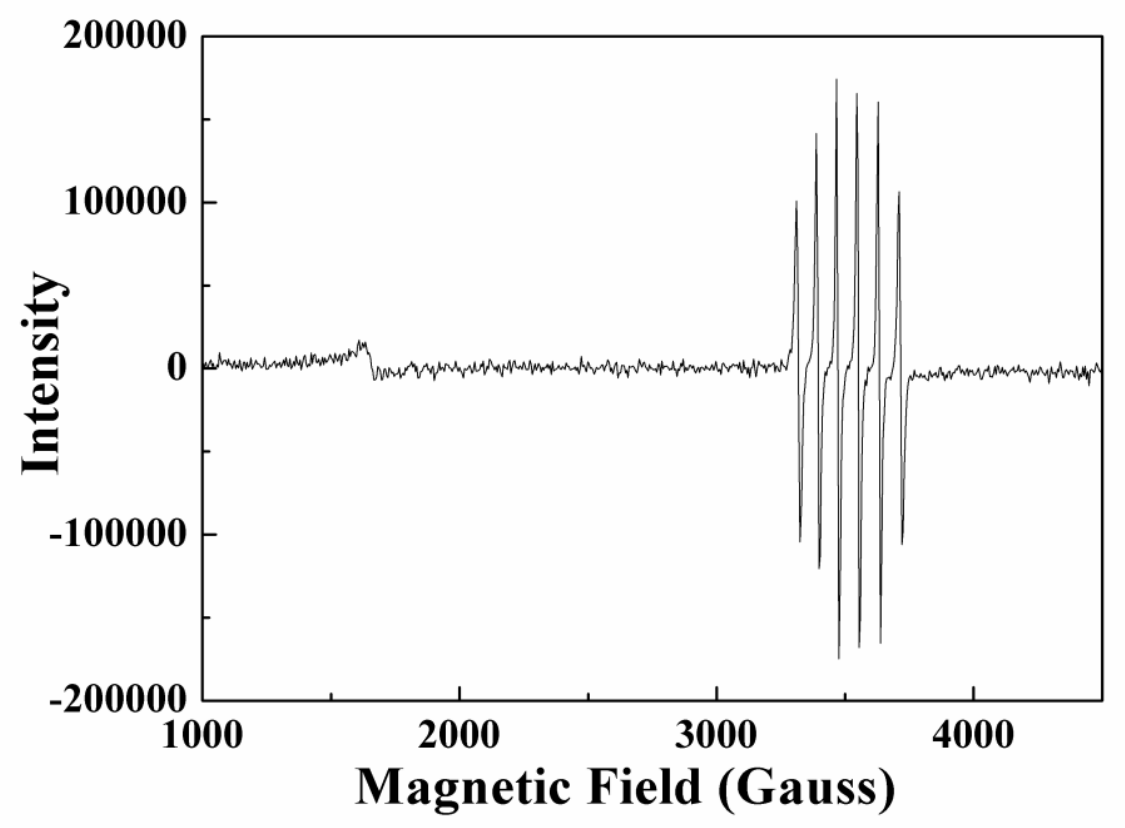

Fig. 5. X-Band EPR spectrum of recycled $\mathrm{Mn}_{1}$ in $\mathrm{MeCN}$

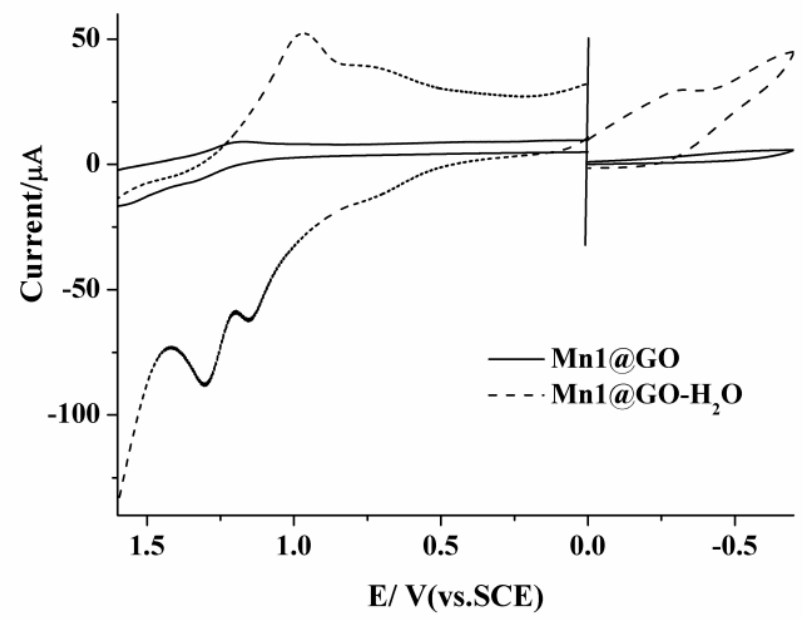

Fig. 6. Cyclic voltammetry curves of solutions of $\mathrm{Mn}_{1} @ \mathrm{GO}\left(\mathrm{C}_{\mathrm{Mn}}, 1 \mathrm{mM}\right)$ in dry $\mathrm{MeCN}$ (black line), $\mathrm{Mn}_{1} @ \mathrm{GO}$ in $\mathrm{MeCN}: \mathrm{H}_{2} \mathrm{O}=6: 1$ (dashed line) at $298 \mathrm{~K}$ (vs SCE), platinum working electrode, $100 \mathrm{mV} / \mathrm{s}$ scan rate. 


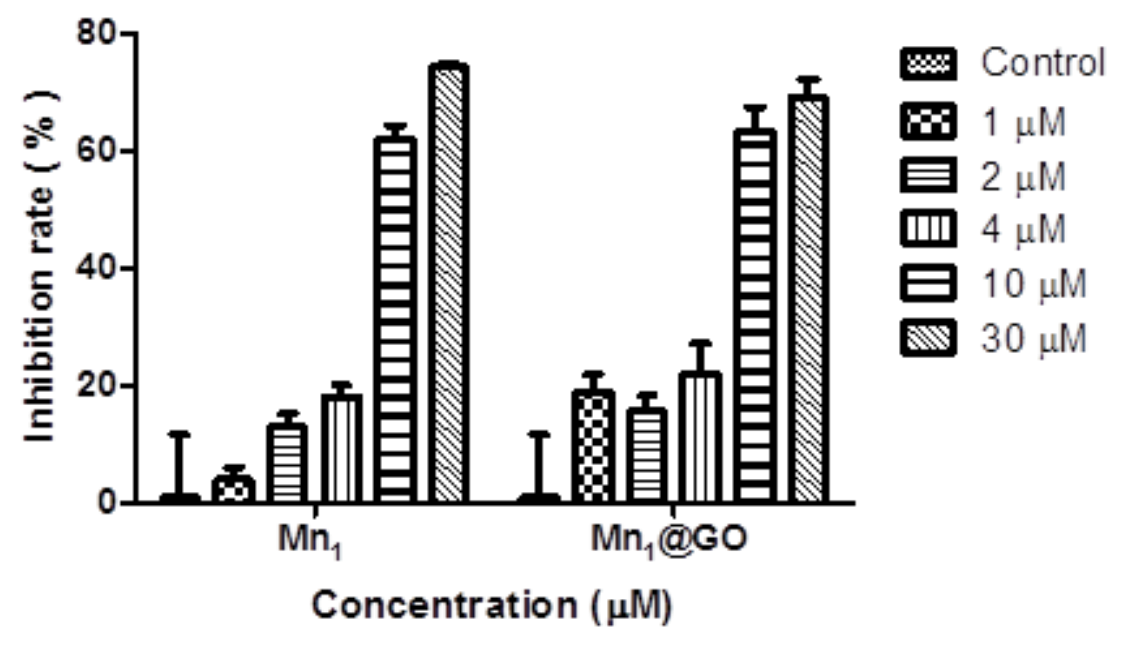

Fig. 7. Inhibition activities of $\mathrm{Mn}_{1}$ and $\mathrm{Mn}_{1} @ \mathrm{GO}$ on the proliferation of HepG-2 cells. HepG-2 cells without compounds were used as controls.

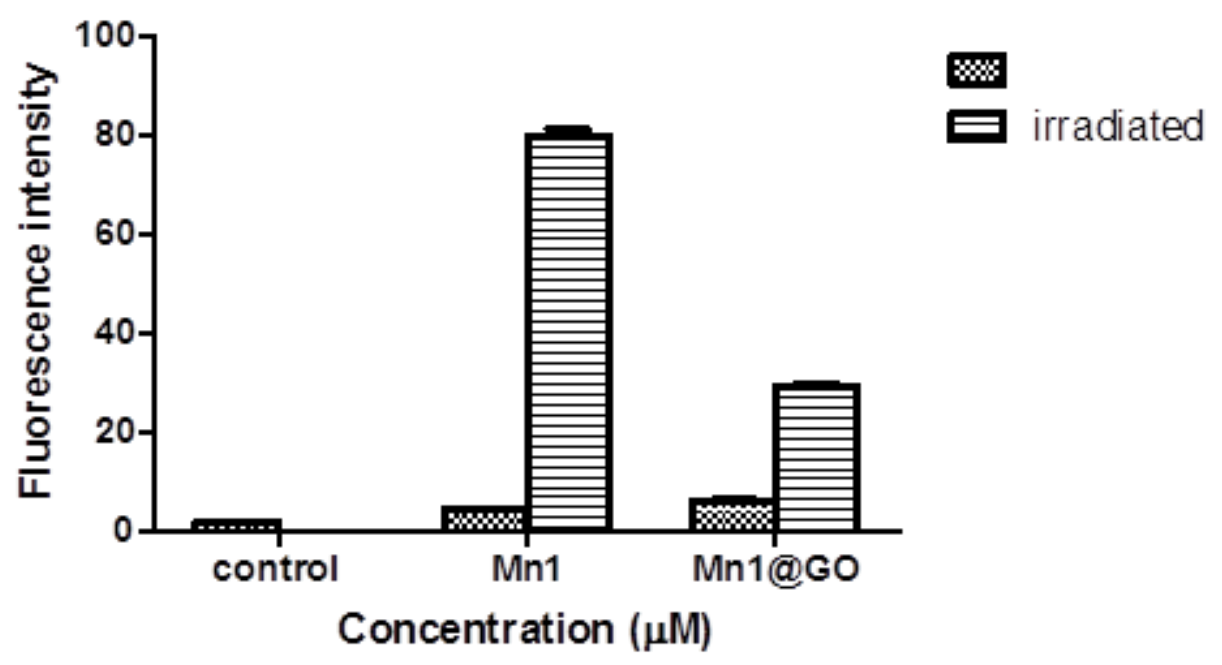

Fig. 8. Effect on the ROS content in HepG-2 for $\mathrm{Mn}_{1}(1 \mu \mathrm{M})$ and $\mathrm{Mn}_{1} @ \mathrm{GO}\left(\mathrm{C}_{\mathrm{Mn} 1}, 1 \mu \mathrm{M}\right)$. 


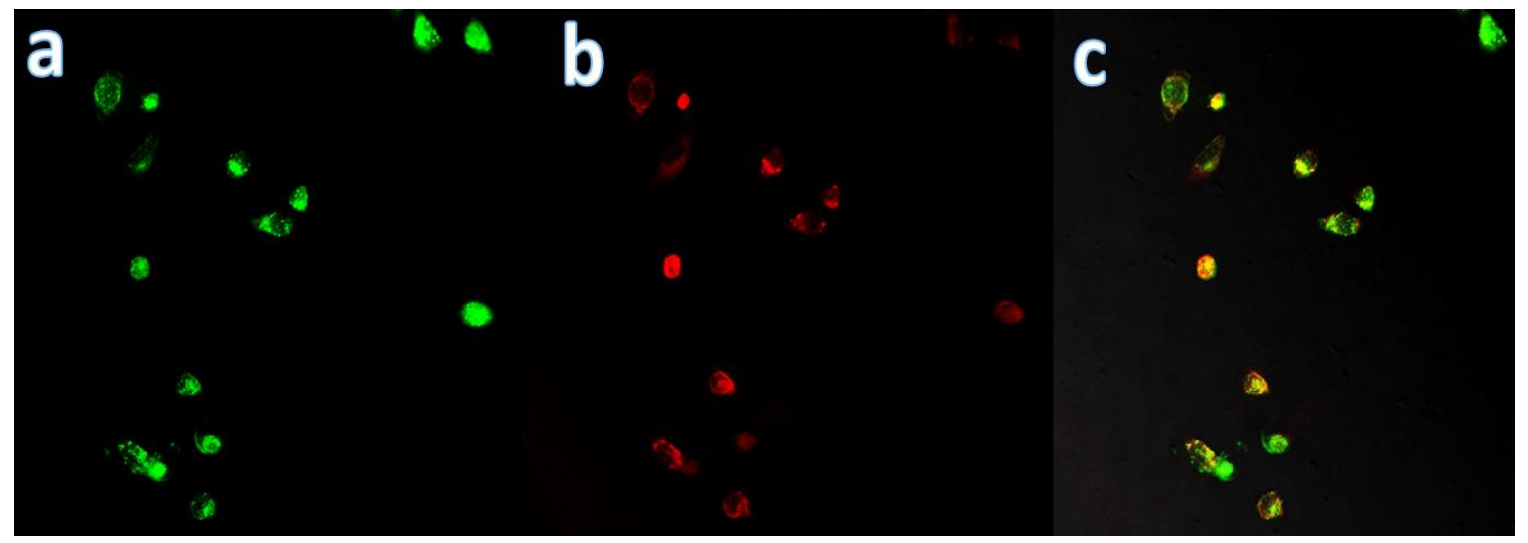

Fig. 9. Fluorescence image of $\mathrm{Mn}_{1}(10 \mu \mathrm{M})$ in HepG-2 cells. a: $\mathrm{Mn}_{1}$ imaging; b: MitoTracker Red FM imaging; c: Overlapped imaging of $\mathrm{Mn}_{1}$ and MitoTracker Red FM.

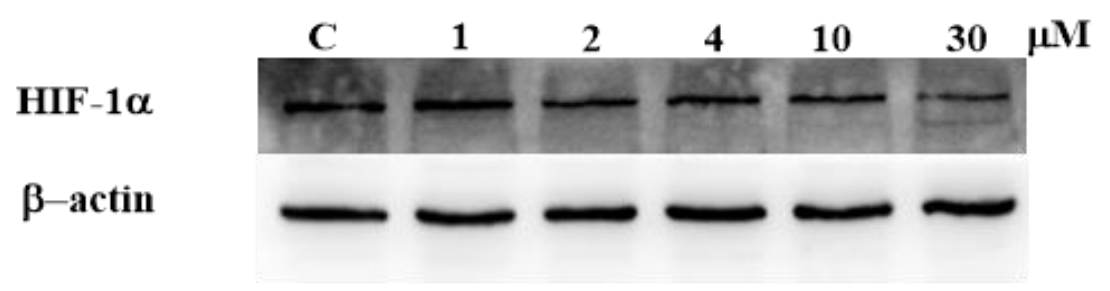

Fig. 10. The expression of HIF-1 $\alpha$ in HepG-2 cells after incubated with different concentrations of $\mathrm{Mn}_{1}$ for $24 \mathrm{~h}$. Control (10 $\mu \mathrm{M}$ DMSO). 